Syverstad, E. \& Nymark, S. (2016). Yrkesrelevante oppgaver i praktisk pedagogisk utdanning for yrkesfag. Scandinavian Journal of Vocations in Development. http://dx.doi.org/10.7577/yu.1613.

Fagfellevurdert artikkel

\title{
Yrkesrelevante oppgaver i Praktisk pedagogisk utdanning for yrkesfag
}

\section{Forfattere:}

\section{Elisabeth Syverstad ${ }^{1} \&$ Solfrid Nymark ${ }^{1}$}

${ }^{1}$ Høgskolen i Oslo og Akershus, Fakultet for lærerutdanning og internasjonale studier, Institutt for yrkesfaglærerutdanning. Postboks 3, St. Olavsplass, N-0130 Oslo.

Korresponderende forfatter: elisabeth.syverstad@ hioa.no

Nøkkelord: yrkesrelevant, studentaktive oppgaver, studentmedvirkning 


\begin{abstract}
Abstrakt
Innledning: Stortingsmelding 27 «Gjør din plikt - Krev din rett» (2000 -2001) utfordrer universitets- og høgskolesektoren til å bruke varierte metoder, begrense antallet forelesninger og legge til rette for studentdeltakelse. På bakgrunn av egne erfaringer og tilbakemeldinger fra studenter, valgte en lærer ved Høgskolen i Oslo og Akershus å utvikle yrkesrelevante oppgaver som krever aktiv deltakelse og hvor studentene har medbestemmelse på innholdet. Formålet med studien er å belyse utviklingen av yrkesrelevant kompetanse slik at studentene mestrer det mangfoldet av arbeidsoppgaver de møter som lærere. Metode: I perioden fra 2010-2015 deltok 84 studenter og en faglige ansatt i et aksjonsforskningsprosjekt ved Praktisk pedagogisk utdanning for yrkesfag (PPU-y). Studentene analyserte lærerens arbeidsoppgaver, og utarbeidet i samarbeid med lærer på høgskolen en oversikt over yrkesfunksjoner og nøkkelkvalifikasjoner i profesjonsutdanningen. Spørreskjemaer, gruppesamtaler og muntlige tilbakemeldinger inngikk i datainnsamlingen som dannet grunnlaget for analysene. Resultat: Data ble analysert innenfor tre hovedområder: Yrkesrelevant opplæring, Medbestemmelse på innhold- og organisering av studiet og Læringsutbytte. Sammenfattende viser dataene at studentene opplever helhet og sammenheng i opplæringen gjennom bruk av yrkesrelevante aktive studentoppgaver. De studentaktive oppgavene ble opplevd som relevante for læreryrket, og skapte en dypere forståelse av det teoretiske fundamentet læreryrket bygger på. Samtidig viser dataene at medbestemmelse ble opplevd som læringsfremmende og motiverende. Konklusjon: Dataene antyder at yrkesrelaterte studentaktive oppgaver har en positiv effekt på studenters motivasjon og opplevelse av eget læringsutbytte, og gir en opplevelse av helhet og relevans i utdanningen.
\end{abstract}

\begin{abstract}
:
Background: White paper no. 27 (2000) "Do your duty - demand your right" challenges universities and colleges to use a variation of methods, limit the amount of lectures and facilitate student participation. Due to feedback from students and personnel experience searched for a vocational relevant student tasks emphasizing active participation. Aim: The aim of the study was to develop student tasks to enhance vocational competence. Method: The study was based on Action Research and performed during the years 2010 to 2015 including participant observation, reflection notes, shadowing, a structured literature search and interviews. In all 84 vocational teacher students and two academic staff members were included. Data were analyzed by a phenomenologic approach within recursive abstraction. Results: The data showed that active participation increased comprehension and was experienced at highly motivating as a result of relevant vocational teacher tasks. Participating in student-active projects was perceived as highly relevant by supporting ability to comprehend theoretical concept. Furthermore, the students influenced was seen to improve learning outcome. Conclusion: The results of the study imply that student-active projects have a substantial effect on the students' motivation, learning outcome, and complete understanding and relevance of the education.
\end{abstract}




\section{Innledning}

«Dagens kunnskapssamfunn gjør at skolen må vare i stand til å forandre seg og legge til rette for kontinuerlig loering» (St. meld. nr. 30, 2004)

Høyere utdanning skal gi studenter perspektiver, kunnskaper, ferdigheter og kompetanse som er relevante for det yrket og den profesjonen de utdanner seg til. For å skape god kvalitet i opplæringen bør innholdet være yrkesrelevant og gi studentene en helhetlig forståelse for oppgavene de vil møte i yrket/profesjonen. Dette innebærer at læringsaktivitetene er forankret $\mathrm{i}$ arbeidet som yrkesfaglærer og i Rammeplanen for praktisk pedagogisk utdanning for yrkesfag (PPU-y). I mange studier blir opplæringen i dag tilpasset studiestrukturen og de administrative rammene. Denne studien handler om hvordan studentene i PPU-y kan arbeide med oppgaver som er relevante for dem som framtidige yrkesfaglærere. Både faglig-, didaktisk- og pedagogisk kompetanse hos de som veileder og underviser studentene, påvirker graden av læring. Studentene lærer best dersom de aktivt deltar i læreprosessene i utdannelsen. Dette innebærer at de ikke bare er mottakere, men også ansvarlige deltagere for egen og medstudenters læring.

I St. meld. nr. 27 (2000-2001) hevdes det at bare et begrenset spekter av undervisningsmetoder er i bruk ved universiteter og høyskoler. Mest brukt er en kombinasjon av forelesninger og selvstudium i tillegg til et begrenset omfang av seminargrupper. UHsektoren ble derfor utfordret til å bygge undervisningen på et større mangfold av undervisningsmetoder. Målet er større intensitet, bedre oppfølging av hver student, og mer studentdeltakelse i planlegging av litteratur og undervisningsformer (St.meld. nr. 27 (20002001). Når studentene deltar og opplever helhet, sammenheng og relevans, fører dette til bedre læringsutbytte (Aamodt, Prøitz, Hovdhaugen \& Stensaker, 2007). På bakgrunn av denne stortingsmeldingen er det ønskelig å utvide spekteret av undervisningsmetoder, og legge til rette for økt studentmedvirkning. Dersom studentene opplever en reell, meningsfull og yrkesforankret utdanning, innebærer det en styrket kvalitet på utdanningen, undervisningen og studentenes læring (Nilsen \& Haaland, 2013).

PPU-utdanning for yrkesfaglærere har som mål å gi studentene yrkesrelevant kompetanse og sette dem i stand til å håndtere det mangfoldet av arbeidsoppgaver studentene møter som lærere (Rammeplan, 2003; Forskrift om rammeplan, 2013). Før innføringen av de studentaktive oppgavene var undervisningen basert på temaundervisning med utgangspunkt $\mathrm{i}$ 
mål fra fagplanen som i 2013 fikk betegnelsen Programplan, praktiskpedagogisk utdanning (HiAK, 2003). Studentene fikk forelesninger med og uten PowerPoint-presentasjoner, dialogundervisning og noen gruppeoppgaver koblet opp mot temaene. Problemet med temabasert undervisning var at mange studenter opplevde undervisningen som lite relevant. Forskning viser at studentene følte seg dårlig rustet til å utføre de arbeidsoppgavene som ble forventet av dem som lærere (Hiim, 2010). De etterlyste metoder og kunnskaper som kunne brukes i og utenfor klasserommet (Goth \& Schön, 2014; Hiim, 2010 ; Høihilder, 2014). Det kognitive og det sosiokulturelle perspektivet er grunnleggende prinsipper for læring. Wilson \& Matsui (1998) fant at jo større den kognitive effekten er, jo mindre innsats behøves for å oppleve relevans. Vi konstruerer kunnskap gjennom å delta i praktiske undersøkende aktiviteter og i interaksjon med omgivelsene (Dewey, 2005; Schøn, 2001). Det er her studentaktive oppgaver finner sin plass. I denne studien brukes begrepet studentaktive oppgaver, som betyr at studentene arbeider med utfordringer de vil møte i arbeidslivet (Frougner, 2010). Studiens mål var derfor å videreutvikle den eksisterende undervisningen ved å bruke studentaktive oppgaver som reflekterer situasjoner fra læreryrket. Slik ønsket vi at studentene skulle oppnå relevant kompetanse som setter dem i stand til å mestre arbeidsoppgavene de vil møte som yrkesfaglærere.

\section{Problemstilling og forskningsspørsmål}

Studien har som overordnet problemstilling:_Hvordan kan PPU-Y-studenter utvikle yrkesrelevant kompetanse til å mestre det mangfold av arbeidsoppgaver de moter som yrkesfaglarere?

Studien skal gi svar på følgende forskningsspørsmål:

1. Hvordan kan studentaktive oppgaver fremme en yrkesrelevant lærerkompetanse?

2. Hvordan kan studentene få medbestemmelse på innhold og organisering av PPU-ystudiet?

3. Hvilke læringsaktiviteter mener studentene gir dem relevant læringsutbytte? 


\section{Definisjon, teori og metode}

\subsection{Definisjon}

Kompetanse blir beskrevet som evnen til å mestre en kompleks utfordring eller utføre en kompleks aktivitet eller oppgave. Internasjonalt blir kompetanse definert som en kombinasjon av kunnskaper, ferdigheter og holdninger som passer i kontekst (St. meld. nr. 30 (20032004)). Nøkkelkompetanse blir definert som kompetansen den enkelte trenger for å kunne ivareta personlig realisering og utvikling, aktivt medborgerskap, sosial inkludering og sysselsetting (European Reference Framework, 2007). Yrkesrelevant kompetanse innebærer i artikkelen at innholdet oppleves meningsfullt og relevant for yrkesutøvelsen som yrkesfaglærer (Hiim, 2010).

\subsection{Teori}

Studiens teoretiske forankring ligger i en sosiokulturell og en kognitiv forståelse av læring. Den sosiokulturelle forståelsen av læring legger vekt på at kunnskap blir konstruert gjennom praktiske aktiviteter der grupper samhandler innenfor et kulturelt fellesskap. Det innebærer at læring forutsetter et praksisfellesskap. Læring skjer gjennom samhandling i en kontekst, ikke primært gjennom individuelle prosesser. Sosiokulturell læring skjer gjennom aktiv bruk av språk og kommunikasjon (Dysthe \& Engelsen, 2003).

Den kognitive forståelsen av læring ses i lys av Kolbs erfaringslæring, som fokuserer på hvordan hjernen bearbeider det verbale eller tallmessige materialet. Dette skjer slik at venstre hjernehalvdel og individets følelsesmessige og helhetlige oppfatning av konteksten integreres med den høyre (Kolb \& Mc Intyre, 1986). Han mener at det skal være rom for å oppleve, erfare og reflektere. Det skal også være rom for å konstruere viten, generalisere og danne nye teorier, eksperimentere og prøve ut nyvunnet innsikt.

Oppgavene studentene arbeidet med var utformet slik at de ga en verbal kognitiv forståelse. De gav også en opplevelsesmessig erfaring koblet mot studentenes læreforutsetninger, noe som gjør at læringen både kan bli teoretisk og praktisk brukbar for studentene (Kolb \& McIntyre, 1986).

De yrkesrelevante og studentaktive gruppeoppgavene har til hensikt å ivareta undervisningens hva, hvordan og hvorfor, og studentenes kognitive forståelse. Argyris \& Schøn (1996, s. 20) skiller mellom to nivåer av læring i grupper: oppgaver med singel-loop og oppgaver med dobbel-loop. Singelloop-oppgaver gir studentene innblikk i hva en lærer må mestre. Oppgaver 
som inkluderer en doble-loop-tankegang konfronterer studentene med egne oppfatninger, synspunkter og erfaringer med medstudenter.

Tosey, Visser \& Saunders (2011) utvidet studentaktive oppgaver med et tredje nivå. Dette nivået, som inkluderer triple-loop, inkluderer etterspørsel av kasusforklaring under en læringsprosess. Her diskuterer studentene hvorfor enkelte løsninger ble valgt, og konkretiserer pedagogiske og didaktiske muligheter. Slik kan læringen ha overføringsverdi til oppgaver de møter som yrkesfaglærere. Studentene skulle få erfaring og kunnskap ved å delta i praktiske undersøkende aktiviteter og i interaksjon med omgivelsene, med påfølgende refleksjon (Dewey, 2005; Schön, 2001).

\subsection{Metode}

Studien, som er basert på aksjonsforskning, dokumenterer prosessene som ble gjennomført i årene 2010-2015 ved Høgskolen i Oslo og Akershus, og inkluderer tre ulike studentkull. Aksjonsforskning (Reason \& Bradbury, 2008) ble valg for å belyse læring i en konstruktivistisk prosess hvor ny kunnskap ble utviklet gjennom systematisk evaluering og analyse, og anvendt i planleggingen av neste periode. Prosessen omfatter en frivilling sosial samhandling mellom forskere (lærere) og praktikere (yrkesfaglærerstudenter) basert på praktikernes medbestemmelse gjennom hele prosessen (McNiff, 2013).

Studien ble gjennomført som en kontinuerlig prosess i fire trinn: planlegging, gjennomføring, observasjon/vurderinger og refleksjon. Data artikkelen bygger på ble innhentet gjennom et strukturert litteraturs $\varnothing \mathrm{k}$, spørreskjemaunders $\varnothing$ kelser, observasjon i klassen og i praksis, og gruppesamtaler som fant sted i tre ulike studentkull i en tidsperiode over fem år.

For å konkretisere, systematisere og visualisere yrkesfaglærerens mangfold av oppgaver utarbeidet PPU-y-studenter og -lærer i samarbeid en oversikt (Tabell 1). Denne dannet grunnlaget i utforming av studentaktive yrkesrelevante oppgavene. 
Tabell 1 Oversikt over yrkesfaglærerens arbeidsoppgaver

\begin{tabular}{|c|c|c|c|c|c|}
\hline $\begin{array}{l}\text { YRKESOPPLAERING } \\
\text { YRKER } \rightarrow\end{array}$ & $\begin{array}{l}\text { FORBEREDELSE } \\
\text { TIL NYTT SKOLEAR }\end{array}$ & SKOLESTART & $\begin{array}{l}\text { YRKESVALG } \\
\text { YRKESKOMPETANSE }\end{array}$ & FAGKOMPETANSE & $\begin{array}{l}\text { AVSLUTNING AV } \\
\text { SKOLEARET }\end{array}$ \\
\hline $\begin{array}{l}\text { YRKES- } \\
\text { FUNKSJONER } \\
\text { Fagkunnskap. } \\
\text { Nøkkel } \\
\text { Kvalifikasjoner } \\
\text { Støttefag } \\
\text { Kommunikasjon }\end{array}$ & $\begin{array}{l}\text { SKOLEN SOM ORGANISASJON } \\
\text { STYRINGSDOKUMENTER } \\
\text { TIMEPLAN } \\
\text { ARSPLANER/UKEPLANER } \\
\text { TVERRFAGLIGE } \\
\text { PERIODEPLANER } \\
\text { BEVISSTGJøRING AV EGEN } \\
\text { KOMPETANSE }\end{array}$ & $\begin{array}{l}\text { TRYGG SKOLESTART } \\
\text { KLASSELEDELSE/ } \\
\text { KONTAKTLFERER } \\
\text { LERINGSMILJø } \\
\text { SKOLEREGLEMENT } \\
\text { ELEVENES } \\
\text { RETTIGHETER } \\
\text { OG PLIKTER }\end{array}$ & $\begin{array}{l}\text { LEERERENS } \\
\text { KUNNSKAP OM } \\
\text { YRKENE INNEN ET } \\
\text { PROGRAMOMRADE }\end{array}$ & $\begin{array}{l}\text { HELHET OG } \\
\text { SAMMENHENG } \\
\text { PROSJEKT } \\
\text { TIL FORDYPNING PTF } \\
\\
\text { INTERESSE } \\
\text { DIFFERENSIERING }\end{array}$ & \begin{tabular}{|l|} 
REELLL \\
FORMELL \\
KOMPETANSE
\end{tabular} \\
\hline $\begin{array}{l}\text { Lover og regler } \\
\text { Observasjon }\end{array}$ & $\begin{array}{l}\text { YRKESDIDAKTISKE } \\
\text { OPPGAVER } \\
\text { YRKESOPPLAERINGENS } \\
\text { HISTORIKK }\end{array}$ & $\begin{array}{l}\text { ELEVSAMTALEI } \\
\text { UTVIKLINGSSAMTALE } \\
\text { TILPASSET } \\
\text { OPPLAERING } \\
\end{array}$ & $\begin{array}{l}\text { VEILEDNING } \\
\text { TAUS KUNNSKAP } \\
\text { YRKESRETTING } \\
\text { YRKESFORANKRING } \\
\end{array}$ & $\begin{array}{l}\text { KOMPETANSEMAL } \\
\text { LEERINGSMAL }\end{array}$ & $\begin{array}{l}\text { GJENNOMFøRING AV } \\
\text { AVSLUTTENDE } \\
\text { PRøVER }\end{array}$ \\
\hline $\begin{array}{l}\text { Samarbeid } \\
\text { Ergonomi } \\
\text { Kontorarbeid } \\
\text { Vedlikehold av utstyr } \\
\text { Grunnleggende } \\
\text { ferdigheter: }\end{array}$ & $\begin{array}{l}\text { ELEVER MED FORTRINNSRETT } \\
\text { TILRETTELEGGING } \\
\text { INFORMASJONSFLYT } \\
\text { UNGDOMSKULTURER } \\
\text { FLERKULTURELLE ELEVER }\end{array}$ & $\begin{array}{l}\text { SKOLEREGLEMENT/ } \\
\text { ORDENSREGLER } \\
\text { TIMEPLAN } \\
\text { FERIE OG FRIDAGER } \\
\text { BøKER OG UTSTYR } \\
\text { LEREPLANER } \\
\text { KULTURELL } \\
\text { SKOLESEKK }\end{array}$ & $\begin{array}{l}\text { REGLER I } \\
\text { ARBEIDSLIVET } \\
\text { ETIKK } \\
\text { BRUK AV IKT I YRKENE } \\
\text { HMS }\end{array}$ & $\begin{array}{l}\text { METODERI } \\
\text { ARBEIDSMATER } \\
\text { VURDERING AV OG } \\
\text { FOR LFERING } \\
\text { ERGONOMI } \\
\text { VEDLIKEHOLD AV } \\
\text { UTSTYR } \\
\text { FAGKOMPETANSE } \\
\text { YRKESKOMPETANSE }\end{array}$ & \begin{tabular}{|l} 
KARAKTERER \\
AVSLUTTENDE \\
PRøVER OG \\
EKSAMEN
\end{tabular} \\
\hline $\begin{array}{ll} & \text { ferdigheter } \\
\text { - } & \text { Muntlige } \\
\text { ferdigheter } \\
\text { - } \\
\text { - } ~ & \text { \&unne lese } \\
\text { - } & \text { Aunne regne } \\
\text { - } & \text { kunne skrive }\end{array}$ & $\begin{array}{l}\text { SAMARBEID MED } \\
\text { ARBEIDSLIVET } \\
\text { OPPGAVER OG INNHOLD I } \\
\text { PROSJEKT TIL FORDYPNING } \\
\text { (PTF) } \\
\text { BEHOV FOR OPPDATERING } \\
\text { KONFLIKTHANDTERING }\end{array}$ & $\begin{array}{l}\text { TEAM SAMARBEID I } \\
\text { SKOLEN OG MED } \\
\text { FORESATTE } \\
\text { BYGGE GODE } \\
\text { RELASJONER } \\
\text { KLASSELERERRAD }\end{array}$ & $\begin{array}{l}\text { OPPGAVERIYYRKER } \\
\text { INTERESSE- } \\
\text { DIFFERENSIERING }\end{array}$ & $\begin{array}{l}\text { PRAKTISKE OG } \\
\text { TEORETISKE } \\
\text { OPPGAVER I FAGENE } \\
\text { PA SKOLEN }\end{array}$ & $\begin{array}{l}\text { ARSKURSBEVIS } \\
\text { VITNEMAL }\end{array}$ \\
\hline
\end{tabular}

Innhold i Tabell 1 (utarbeidet 2010) tar utgangspunkt i Forskrift til Opplæringsloven (2006), lærerplaner for ungdomstrinnet og videregående opplæring (Kunnskapsdepartementet, 2006) og Rammeplanen for praktisk-pedagogisk utdanning (2003). De studentaktive oppgavene som er basert på kunnskap nevnt i Tabell 1 ble utformet for å ivareta nivåene simple-, doble- og triple loop (Reason \& Bradbury, 2008) og læringsutbyttebeskrivelsene i programplan for PPU-y. For å kunne løse oppgavene må studentene reflektere over alle målene fra rammeplanen (HiOA, 2003).

Oppgavene ble primært gjennomført i studentgrupper med 4-6 deltakere med fokus på «refleksjon-i-handling» og «refleksjon-over-handling» (Schøn, 2001). Oppgaveformuleringen tok utgangspunkt i studentenes erfaringsbakgrunn og nivå basert på innspill fra tidligere diskusjoner og refleksjoner (Hatti, 2013).

Informantene: De 84 informantene var deltidsstudenter ved PPU, Høgskolen i Oslo Akershus. Studentene hadde en gjennomsnittsalder på 40 år, generell studiekompetanse og minimum to års yrkesteoretisk utdanning, og 4 års relevant praksis.

Spørreskjema: Spørreskjemaet ble utarbeidet i samarbeid med en av de forskningsansvarlige ved instituttet, og inkluderte åpne kvalitative spørsmål og lukkede, prekodete spørsmål. 
Besvarelsene ble behandlet konfidensielt, og noen av opplysningene blir senere i artikkelen sitert i avidentifisert form. Datainnsamlingene som baserer seg på spørreskjemaer er gjennomført 6 ganger i året. Utformingen av spørsmål ble diskutert med kolleger for å øke den interne validiteten.

Gruppesamtaler: I de to første studentkullene ble det gjennomført 2 fokusgruppesamtaler (Patton, 2002). Fokusgruppene inkluderte gjennomsnittlig 4 informanter med ulik fag- og erfaringsbakgrunn (Johannessen et al., 2011). Gruppesamtalene ble gjennomført for å verifisere data som ble innhentet gjennom spørreskjemaene. Det ble ikke tatt lydopptak. Analyse: Datainnsamling og analyse foregikk kontinuerlig basert på fortetning (Reason \& Bradbury, 2008). Informantenes oppfatning ble kodet og deretter plassert i kategorier. Analysen ble foretatt av begge forfatterne (ES og SN). Analysen av data ble deretter presentert for de respektive kull og diskutert med mål om å fremme den interne validiteten (Johannessen et al, 2011; Patton, 2002).

Systematisk litteraturs $\emptyset \mathrm{k}$ : Det ble gjennomført et strukturert litteraturs $\emptyset \mathrm{k}$ (Patton, 2002) som inkluderte nøkkelordene «yrkesrelevant*», «studentaktiv*» og «medbestemmelse*» på norsk og engelsk i database Oria, Nordart og ERIC. Søket resulterte i 29 fagbøker og fire vitenskapelige artikler hvorav fire bøker og tre vitenskapelige ble inkludert i artikkelen. Hermeneutisk bakgrunn og forskernes arbeidsfordeling: Generalisering av forskning baserer seg ofte på selektive inntrykk (Johannessen et al. 2011; Kvale, 2001). Forfatterne, som begge er ansvarlige for undervisning av PPU-y, har lang erfaring fra undervisning i lærerutdanning. ES har, som initiativtaker og prosjektleder, gjennomført datainnsamlingen og utarbeidet de studentaktive oppgavene.

Etikk: Før studien ble initiert, ble den beskrevet for informantene. De ble fortalt at deltakelsen var frivillig. Anbefalte retningslinjer samt forskningsetiske prinsipp er fulgt gjennom hele studien (Johannessen et al., 2011). ES hadde samtidig rolle som forsker og klasseleder. Maktproblematikken ble oppfattet som et etisk dilemma, og forskeren var bevisst dobbeltrollen som kan ha påvirket resultatet. Studien er godkjent av Norsk Samfunnsvitenskapelig datatjeneste (NSD) med prosjektnummer 39998. 


\section{Resultat og diskusjon}

Analyser av dataene identifiserte tre hovedresultater: Yrkesrelevant opplaring, Medbestemmelse på innhold \& organisering av studiet, Laringsutbytte.

\subsection{Yrkesrelevant opplæring}

Jeg er veldig fornøyd. Har blitt mer strukturert som lærer. Denne kunnskapen har jeg ikke klart å lære ved kun praksis. Så vet ikke hva som kunne blitt gjort bedre. () (Student nr. 21, Kull 1)

Å forankre teori og arbeidsmåter i studentenes framtidige jobb som yrkesfaglærere var grunnleggende for å sikre et yrkesrelevant PPU-y-studium. Studentenes mulighet for medbestemmelse var en viktig faktor for videreutviklingen. Samtidig ble en kontinuerlig analyse av studentenes tilbakemeldinger grunnlaget for endring i tilnærmingsmåte (Bø \& Helle, 2010 s. 189). Våre data viser at innholdet og læreprosessene må gi studenten erfaringen med å løse praktiske utfordringer i læreryrket slik at de er i stand til å mestre mangfoldet av arbeidsoppgaver de vil møte som lærere, og profesjonsutdannere (St.meld. nr. 27 (20002001)).

Data som ble innhentet fra de inkluderte årskull, viser at studentaktive oppgaver oppleves relevante for læreryrket, og teorien er aktuell for å utvikle egen kompetanse i yrkesdidaktikk og pedagogikk.

Vi husker og lærte mye fra de praktiske $\varnothing$ velsene (blomsteroppsett, kommunikasjonsøvelser, slipsknyting) Den didaktiske relasjonsmodellen koblet mot praktiske oppgaver gir oss kompetanse, og vi kan bruke denne i undervisning og gruppearbeid. (Gruppe 3, Kull 2)

Studentene opplevde at de, gjennom de studentaktive oppgavene, utviklet både kunnskap, ferdigheter og holdninger ved å koble praktisk aktivitet og relevant teori, og at de utviklet reell yrkeskompetanse. Dette samsvarer med Konfluent pedagogikk, der kognitive, affektive og psykomotoriske kunnskaper skal flyte sammen til en helhetlig læring og gi erfaring som blir generalisert mot oppgaver de senere skal håndtere i læreryrket (Grenstad, 1998).

Basert på Spørsmål 2 (Appendiks 1) viser analysen at 94\% av studentene opplevde de praktiske oppgavene som ble gjennomført på samlingene som meningsfulle. En student uttrykte det slik:

Jeg synes omtrent alle samlingene har vært nyttige og gode. Nesten alltid gått ut fra timene med ny lærdom og lyst til å lære mer. (Student nr. 25, Kull 1) 
En annen student uttrykte det på en tilsvarende måte:

Veldig fornøyd med opplegget, synes jeg har lært veldig mye.» (Student nr. 12, Kull 1)

Her viser studentenes svar at opplæringen ble opplevd som yrkesrelevant samt at $\varnothing$ velsene fremmer ønske om kompetanseøkning (Schön, 2001). Disse studentene hadde fått erfaringslære gjennom refleksjon i og over handling noe som fremmet at innholdet ble oppfattet som meningsfullt.

\subsection{Medbestemmelse på innhold og organisering av studiet}

Gjennom den systematiske aksjonsforskningen bidro studentene jevnlig med sine synspunkter. De var aktive i læreprosessene, observerte og reflekterte over det som skjedde i gjennomføringen. De fikk innblikk i svarene fra spørreskjemaene, og bidro til endringer underveis i studieforløpet (Reason \& Bradbury, 2008; Mc Niff, 2013). Et overraskende element var at sirklene i forskningsprosessen utviklet seg slik at det også oppsto «småsirkler». Disse innebar at studentene, som et resultat av de læreprosessene de var en del av, uttrykte et behov for konkretisering og mer teori (Mc Niff, 2002:57).

Under studien stod praksisteori sentralt. Studentenes tilbakemeldinger bidro til deres sosiokulturelle læring. Denne læringen baserte seg på et stadig foranderlig system av kunnskap, erfaring og verdier med betydning for studentenes undervisningspraksis (Handal \& Lauvås, 1999:19).

Basert på tilbakemeldinger fra tidligere kull ble årsplanen for PPU-y utarbeidet i samarbeid mellom studentene og klasseansvarlig, og revidert ved studiestart av nye kull. For å kontrollere at årsplanen ble opplevd som relevant stilte vi seks mnd. etter utarbeidelsen av årsplanen følgende spørsmål: «Har du synspunkter på innholdet av årsplan?» Studentene svarte uniformt på spørsmålet.

En av studentene uttrykket det slik:

Jeg synes den ser bra ut. Flott at du tilpasser planen underveis (Student nr. 1, Kull 1)

Og en annen student uttrykket det slik:

Synes det virker bra, ser fram til å lære mer innen disse områdene.

(Student nr.2, Kull 1) 
Det kom også mer informative tilbakemeldinger som:

Synes at det så langt har vært svært god «timing» i forhold til det som skjer i egen yrkespraksis. Eks. Skolestart, periodeplan. Nyttig og praksis nær tilnærming. Fortsett med praktiske $\emptyset$ velser i tilknytning til teori i like stor grad som i dag. Jeg merker at jeg forstår og husker teorien bedre ved hjelp av praktiske øvelser. (Student nr.16, Kull 2)

Basert på studentenes tilbakemelding mener vi at de opplevde læringsarbeidet som meningsfullt og relevant for læreryrket, og at de utviklet god forståelse for sammenhengen mellom teori og praksis (Dewey, 2005). Forfatterne kunne observere at studentene utøvde aktivitet gjennom praktiske læringsaktiviteter og interaksjon med andre. Data viste videre at studentene gjennom interaksjon fikk erfaring og lærte om samspill i kontekster. Det ble videre observert at studentenes erfaring ble rekonstruert på bakgrunn av refleksjon. Studentenes forståelse for innholdet i studiet ble utfordret, og bidro til økt handlingskompetanse og en bevisst holdning knyttet til arbeidet som yrkesfaglærer.

\subsection{Læringsutbytte}

Rapporten Læringsutbytte i høyere utdanning stiller spørsmål om hvordan det skapes et godt læringsutbytte (Aamodt el al., 2007, s. 54). Her går det fram at læringsmiljøer, undervisningsmetoder og undervisningsopplegg skal bidra til å utvikle evner til samarbeid, selvrefleksjon, autonomi og problemløsing. Det helhetlige læringsutbyttet beskrives som resultatkvalitet i denne sammenhengen (NOU 2003:16).

Kognitive, affektive og psykomotoriske ferdigheter er den helhetlige forståelsen studentene utvikler, husker og kan bruke i det mangfold av oppgaver de møter som yrkesfaglærere. Forfatterne, som også var undervisningspersonell for studentene, erfarte at små studentaktive oppgaver kan fremme yrkesrelevant læring. Dette fikk ES og SN bekreftet under observasjon i pedagogisk praksis i skolen.

Den verbal-kognitive forståelsen de studentaktive oppgavene formidlet bidro til at læringen ble både teoretisk og praktisk anvendbar for studenten. Dette ble bekreftet under analysen av spørsmål 8 i spørreundersøkelsen (Appendiks 1): «Hvor stort laeringsutbytte føler du å ha hatt så langt $i$ studiet?». 
Figur 1. Læringsutbytte i studiet

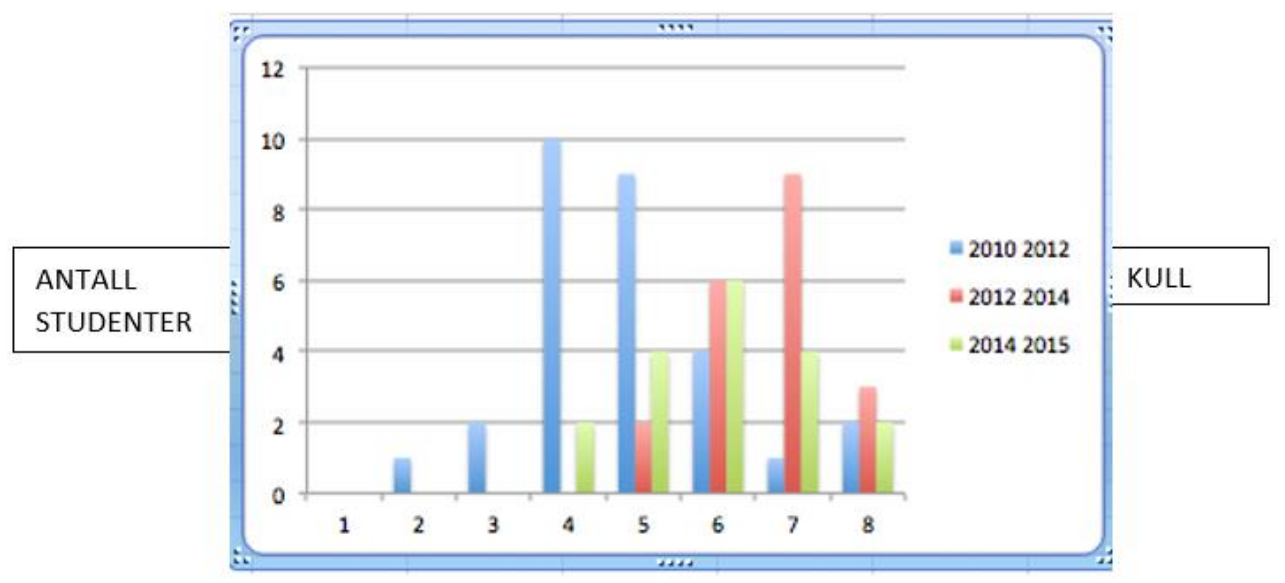

Figur 1 hadde en avkrysning fra 1-8, hvor 1 er opplevelse av et lavt læringsutbytte, og 8 svært høyt. Y-aksen illustrerer antall studenter og X-aksen illustrerer opplevelsen av læringsutbytte og resultatene fra de tre inkluderte kullene er fargekodet slik det er beskrevet i figuren.

Som figuren viser, hadde Kull 1 (blå søyler) en jevn spredning med hovedvekt på svaralternativene 4 og 5 . I kull 2 (røde søyler) har $90 \%$ svart alternativ 6, 7 og 8. I det tredje kullet (grønne søyler) er det mer spredning, og hovedvekten av avkrysning er på 5, 6 og 7 . Som Figur 1 viser, opplever majoriteten av studentene høy score av læringsutbytte ved gjennomføring av studentaktive oppgaver. Læringsutbytte ble opplevd størst i Kull 2. Kull 3 hadde flest studentaktive oppgaver i 1. semesteret (14 oppgaver), men de har bare vært deltakere i aksjonsforskningen i 1 . semester.

I denne konteksten kan følgende tilbakemelding være representativ:

Jeg savner litt mer effektiv bruk på samlingene med gjennomgang av fagstoff, men samtidig er det viktig å ha praksis også og ønsker jeg litt mer teori $(;)$ (Student nr. 11, Kull 3)

En tilbakemelding ga uttrykk for at det kanskje kan bli for mange studentaktive oppgaver i et studium, og at løsning av oppgaver kan gå på bekostning av grundig etterlesing som gir studentene en helhetlig forståelse.

Resultatene av læringsutbyttet for $\varnothing$ vrig viser at få eller mange studentaktive læringsoppgaver per semester ikke er vesentlig for tolking av eget læringsutbytte. Studentene fikk spørsmål med tekst Ordet fritt, slik at de kunne skrive ned synspunkter og tanker om undervisningens 
innhold og organisering. Dette er viktig informasjon til oss som forskere og har ført til endret opplæring. På disse spørsmålene fikk vi tilbakemeldinger som:

Framlegget fra gruppene ble til tider altfor drøyt. Brukes for mye tid på dette.» (Student nr. 8, Kull 1)

Jeg ønsker noen ganger litt mer forelesninger, men det kan jo være angående temaer. (Student nr. 3, Kull 3)

Her ser vi at flere studenter etterlyser bedre oversikt over teori, kapitler og sider på det som skal gjennomgås på neste samling, og en oppsummering med sidehenvisninger på det som er gjennomgått. Utfordringen i prosessene ble å ivareta de ulikes studentenes ønsker.

\section{Konklusjon}

Forfatterne konkluderer med at studentaktive oppgaver som har overføringsverdi til læreryrket og som ivaretar både nøkkel- og yrkeskompetanse kan gi studentene en opplevelse av at opplæring er yrkesrelevant.

For at de skal bidra til å bygge opp yrkesrelevant lærerkompetanse ut fra studentenes forkunnskaper, må de studentaktive oppgavene være utformet slik at de ivaretar alle studentenes læreforutsetninger, som kjønn, alder, yrkesbakgrunn og erfaringer. Mange studenter uttrykte at oppgaveløsingen ga dem handlingskompetanse til å utføre oppgaver i pedagogisk praksis eller i egen lærerjobb. Kompetansen de utviklet på samlinger ble dermed generalisert og kunne benyttes i situasjoner de ville møte som lærere.

I de to første studentkullene etterspurte studentene flere studentaktive oppgaver. Denne forskningen kan derfor være en bekreftelse på at bruk av studentaktive oppgaver gjennomført med ulike undervisningsmetoder, med refleksjon og medbestemmelse, tilpasset studentenes behov, har gitt mange av studentene høyt læringsutbytte. I det tredje studentkullet har studentene beskrevet hvilke oppgaver som ga dem stort og relevant læringsutbytte. De tre studentaktive oppgavene som ble rangert $\varnothing v e r s t$ var: a. Instruksjon i lys av didaktisk relasjonsmodell, b. Kommunikasjonsoppgave med fokus på lederstiler og c. Bevisstgjøring av egen kompetanse knyttet til ungdomstrinnet. Flere av respondentene mente at oppgavene var meningsfulle med tanke på framtidig lærerjobb.De studentaktive oppgavene vil videreføres til nye studentkull, men forskernes erfaringer og nye kunnskaper vil endre noen oppgaveformuleringer og innhold i oppgavene, da også vår praksisteori endres og utvikles. 
Medbestemmelse vil fortsatt bli ivaretatt i alle studentkull. Ved å konkretisere

arbeidsoppgaver i lærerens hverdag erfarte vi at de studentaktive oppgavene ivaretok alle mål/læringsutbyttebeskrivelsene, først fra Fagplan PPU-y (2003) og senere

læringsutbyttebeskrivelser i Programplanen for praktisk- pedagogisk utdanning for yrkesfag (2014). 


\section{Referanseliste}

Aamodt P.O., Prøitz T. S., Hovdhaugen E. \& Stensaker B. (2007). Laringsutbytte i høyere utdanning. En drøfting av definisjoner, utviklingstrekk og måleproblemer. (NIFU STEP rapport nr.40/2007).

Argyris, C. \& Schön, D. (1996). Organizational Learning II. Theory, Method, and Practice. New York: Addison -Wesley Publishing Company.

Bø, I. \& Helle, L. (2010). Pedagogisk ordbok. Praktisk oppslagsverk i pedagogikk, psykologi og sosiologi. 2. utg. Oslo: Universitetsforlaget.

Dewey, J. (2005). Demokrati og uddannelse. Århus: Forlaget Klim.

Dysthe O. \& Engelsen K. S. (Red.).(2003). Mapper som pedagogisk redskap. Perspektiver og erfaringer. Oslo: Abstrakt forlag.

Forskrift til opplæringslova (2006). Forskrift til opplaeringslova. Hentet den 16.02.2016 fra https://www.lovdata.no

Forskrift om rammeplan (2013). Forskrift for praktisk-pedagogisk utdanning for yrkesfag for trinn 8-13. Hentet den 01.02.2016 fra https://www.lovdata.no

Frougner, M. (2010). Hva slags caseoppgaver inviterer til studentaktivitet og interaksjon? Norsk tidsskrift for helseforskning 6(1)72-82.

Goth, U.S. \& Schön, E.M. (2015). "Learning by doing....”. Nordic Journal of Education and Vocational Research (4)1-22. doi: 10.3384/njvet.2242-458X.14v4i1

Grenstad, N. M. (1998). Å laere er å oppdage. Oslo: Didakta Norsk Forlag.

Handal, G. \& Lauvås P. (1999). På egne vilkår. En strategi for veiledning med larere. Oslo: Cappelen Akademiske forlag.

Hiim, H. (2010). Pedagogisk aksjonsforskning- tilnarminger, eksempler og kunnskapsfilosofisk grunnlag. Oslo: Gyldendal Akademisk.

Hiim, H. (2013). Praksisbasert yrkesutdanning: hvordan utvikle relevant yrkesutdanning for elever og arbeidsliv? Oslo: Gyldendal akademisk.

Høgskolen i Akershus, Fagplan for praktisk-pedagogisk utdanning. 17. juni 2003.

Høihilder, E. K. (2014). Pedagogikk 8 - 13 trinn. Profesjonsutdanning av larere. Oslo: Gyldendal akademisk.

Kvale, Steinar (2001). Det kvalitative forskningsintervju. Oslo: Gyldendal Akademisk. Kunnskapsdepartementet (2006). Lareplanverket for Kunnskapslфftet. Oslo: Utdanningsdirektoratet 
Johannessen, A., Christoffersen, L. \& Tufte, P. A. (2011). Forskningsmetode for $\phi k o n o m i s k e$ administrative fag. Oslo: Abstrakt forlag.

Kolb, D. I. \& Mc Intyre J. M. (1986). Organisasjons- og ledelsespsykologi-basert på erfaringslacing, Oslo: Universitetsforlaget.

Mc.Niff, J. \& Whitehead J. (2002). Action Research. Principles and Pratice. (2. utg.) London \& New York: Routledge Falmer.

Mc.Niff, J. (2013). Action Research. Principles and Practice (3 utg) London \& New York: Routledge Falmer.

Nilsen, S. E. \& Haaland, G. (2013). Laring gjennom praksis: innhold og arbeidsmåter $i$ yrkesopplaringen. Oslo: Pedlex Norsk Skoleinformasjon.

Norsk Studentunion, Politisk dokument. Hentet den 10.12.2015 fra http://student.no/content/uploads/2014/05/Politisk-dokument-om-studiekvalitet.pdf

NOU 2003:16. (2003). If $\not$ rste rekke-En forsterket kvalitet i grunnopplaringen for alle. Utredning fra et utvalg oppnevnt ved kongelig resolusjon 05.juni.2003. Oslo: Utdannings - og forskningsdepartementet. Hentet fra http:// www.regjeringen.no. Patton, M. Q. (2002). Qualitative research \& evaluation methods (3 utg.). Thousand Oaks, CA.: Sage Publications.

HiOA (Høgskolen i Oslo og Akershus) (2003). Programplan praktisk pedagogisk utdanning for yrkesfag (PPU-Y). Hentet den 01.10.2015 fra http://www.hioa.no.

Rammeplan for praktisk-pedagogisk utdanning (2003). Rammeplaner for hфyere utdanninger. Hentet den 01.02.2016 fra http://www.regjeringen.no.

Reason, P. \& Bradbury, H. (2008), The Sage Handbook of Action Research (2 utg) London: Sage publications.

Schøn, D. A. (2001). Den reflekterende praktiker. Hvordan profesjonelle tenker når de arbejder. Århus: Forlaget Klims

St.meld. nr. 27 (2000-2001). (2001). Gjør din plikt - Krev din rett. Oslo:

Kunnskapsdepartementet. Hentet den 01.02.2016 fra http://www.regjeringen.no. St.meld. nr. 30 (2003-2004). (2004). Kultur for laring. Oslo: Kunnskapsdepartementet. Hentet den 01.02.2016 fra http://www.regjeringen.no.

Tosey, P., Visser, M. \& Saunders, M.N. (2012).The origins and conceptualizations of 'tripleloop' learning. Management Learning 43 (3)291-307. 
Wilson, D. \& Matsui, T. (1998). Recent appraches to bridging: Truth, coherence, relevance.

UCL Working Papers in Linguistics. 


\section{APPENDIKS}

\section{Appendiks 1 (Informasjon \& evalueringsskjema):}

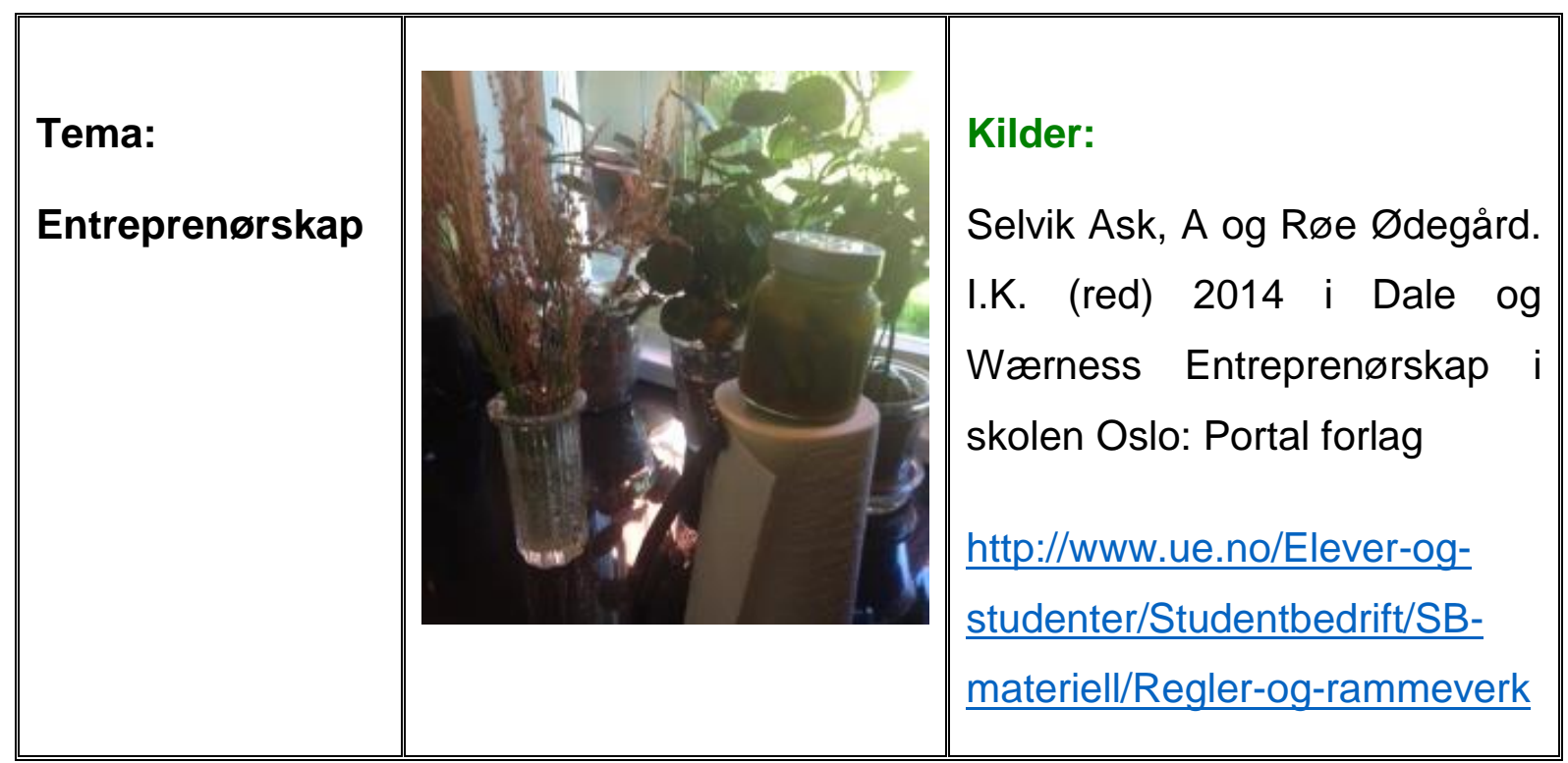

Som yrkesfaglærer er det nødvendig at du har kompetanse om elevbedrift. Du skal kunne veilede elever i arbeidet med å opprette, utvikle og avvikle en bedrift. Elevbedrifter skaper verdier ved kjøp og salg av varer og tjenester og bidrar med innovasjon i samfunnet.

For at du som student skal tilegne deg ovennevnte kompetanse skal du i samarbeid med medstudenter gjennomføre følgende oppgave:

- Gjennomfør en idemyldring og bli enige om hva dere vil utvikle av produkt eller tjenester

- La en skisse som viser innhold og oppbygging av bedriften

- Opprett stillinger og søk på disse. Følgende stillinger skal besettes: 1. Daglig leder, 2. Økonomiansvarlige, 3. Markedsfører.

- Søknadene behandles og ansettelse bestemmes.

- Lag et produkt eller en tjeneste som selger.

Resultatet presenteres for medstudenter. Medstudenter gir tilbakemeldinger på produkt/tjeneste og presentasjon ved å bruke vedlagt skjema.

Gruppa skal hente ut aktuelle læringsutbyttebeskrivelser fra programplanen for PPU-y for å se sammenheng mellom oppgavens innhold og programplanens krav. 


\section{TILBAKEMELDING TIL STUDENT BEDRIFTEN}

\section{Oppgave 1}

Hvordan opplevde dere helhetsinntrykket av produktet eller tjenesten?

6 er svært bra, 1 er lite bra

\begin{tabular}{|l|l|l|l|l|l|}
\hline 6 & 5 & 4 & 3 & 2 & 1 \\
\hline & & & & & \\
\hline
\end{tabular}

Begrunn svaret:

\section{Oppgave 2}

I hvilken grad var bedriften/tjenesten kreativ?

6 er svært bra, 1 er lite bra

\begin{tabular}{|l|l|l|l|l|l|}
\hline 6 & 5 & 4 & 3 & 2 & 1 \\
\hline & & & & & \\
\hline
\end{tabular}

Begrunn svaret:

\section{Oppgave 3}

Hvordan var markedsføring av bedriften?

6 er svært bra, 1 er lite bra

\begin{tabular}{|l|l|l|l|l|l|}
\hline 6 & 5 & 4 & 3 & 2 & 1 \\
\hline & & & & & \\
\hline
\end{tabular}

Har dere råd å gi til bedre markedsføring?

Oppgave 4

I hvilken grad opplevde dere framlegget motiverende og læringsfremmende?

6 er svært bra, 1 er lite bra

\begin{tabular}{|l|l|l|l|l|l|}
\hline 6 & 5 & 4 & 3 & 2 & 1 \\
\hline & & & & & \\
\hline
\end{tabular}

Begrunn svaret:

Oppgave 5

Hvordan vil dere gradere deltakernes formidlingsevne?

6 er svært bra, 1 er lite bra 


\begin{tabular}{|l|l|l|l|l|l|}
\hline 6 & 5 & 4 & 3 & 2 & 1 \\
\hline & & & & & \\
\hline
\end{tabular}

Begrunn svaret:

Bedriftsmedlemmene diskuterer og reflekterer over: Fordeling av ansvar og arbeidsroller.

Samlet vurdering: (A - F) Regnskap og økonomi.

Tilbakemelding fra medstudenter, oppgave 1 - 5

Forslag til evt. endringer. 


\section{Appendiks 2 (Evalueringsskjema)}

MeOSKDLEN I OSL
Oo AKERSHUS

Evaluering av studieåret 2012 - 2013, klasse PPU F

1. Tenk tilbake pá studieáret $2012-2013$. Hva husker du best?

2. Opplever du at de praktiske oppgavene som er gjennomfort pd samlingene, er koblet mot meningsfull og anvendbar teori?

\begin{tabular}{|l|l|}
\hline & Ja \\
\hline & Nei \\
\hline & $\begin{array}{l}\text { Vet } \\
\text { ikke }\end{array}$ \\
\hline
\end{tabular}

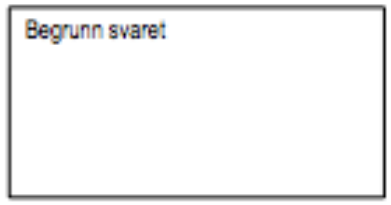

3. Opplever du at arbeidet i studiet gir rom for differensiering?

\begin{tabular}{|l|l|}
\hline & Jat $X$ \\
\hline & Nei \\
\hline & $\begin{array}{l}\text { Vet } \\
\text { ikke }\end{array}$ \\
\hline
\end{tabular}

4. Opplever du à ha hatt reell medbestemmelse pá valg av innhold, oppgaveformulering og presentasjonsformen?

\begin{tabular}{|l|l|}
\hline \multicolumn{2}{|c|}{ Sett $X$} \\
\hline & Ja \\
\hline & Nei \\
\hline & $\begin{array}{l}\text { Vet } \\
\text { ikke }\end{array}$ \\
\hline
\end{tabular}

Begrunn svaret

5. Synes du at det I studiet har vært avsatt for mye tid til a. Diskusjoner

\begin{tabular}{|l|l|}
\hline & Ja \\
\hline & Nei \\
\hline & $\begin{array}{l}\text { Vet } \\
\text { ikke }\end{array}$ \\
\hline
\end{tabular}

Begrunn svare: 
b. Framlegs

\begin{tabular}{|l|l|}
\hline & Satt $X$ \\
\hline & Nei \\
\hline & $\begin{array}{l}\text { Vet } \\
\text { ikke }\end{array}$ \\
\hline
\end{tabular}

6. Opplever du at dette äret har gitt deg didaktisk handlingskompetanse?

\begin{tabular}{|l|l|}
\hline & Ja \\
\hline & Nei \\
\hline & $\begin{array}{l}\text { Vet } \\
\text { ikke }\end{array}$ \\
\hline
\end{tabular}

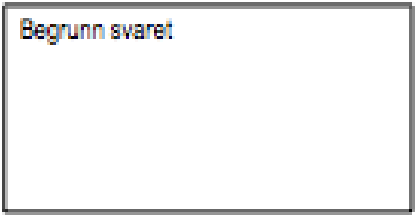

7. Opplever du at tilbakemeiding pá oppgaver har vært gitt slik at du vet hva som má til for a utfore en oppgave enda bedre neste gang?

\begin{tabular}{|l|l|}
\hline & Ja \\
\hline & Nei \\
\hline & $\begin{array}{l}\text { Vet } \\
\text { ikke }\end{array}$ \\
\hline
\end{tabular}

Begrunn svare:

8. Hvor stort læringsutbytte foler du $\mathrm{a}$ ha hatt dette studiedret Sett $\mathrm{X} 1$ er lite 6 er mye

\begin{tabular}{|l|l|l|l|l|l|}
\hline 1 & 2 & 3 & 4 & 5 & 6 \\
\hline & & & & & \\
\hline
\end{tabular}

Hvis du har krysset av for lite læringsutbytte, har du noen tanker om hwa som er ársakene till dette? 
9. Hvordan opplewer du besak av klasselærer I pedagogisk praksis?

10. Vi, Rosaline og Elisabeth ensker noen tilbakemeldinger som gjor at vi bedre kan tilrettelegge for stort læringsutbytte for deg. Derfor trenger vi râd.

\begin{tabular}{|l|l|}
\hline Rad til lærer 1 & Rad til lærer 2 \\
\hline & \\
& \\
& \\
\hline
\end{tabular}




\section{Appendiks 3 (Evaluering av læringsutbytte)}

|

Evaluering av læringsutbytte, fredag 15. oktober 2010.

Hvis du tenker tilbake pá de samlingene vi har hatt fra vi startet i august 2010.

1. Hva husker du best?

2. Hva har du lært (hatt av læringsutbytte) i dag?

3. Vi har gjennomgått innhold $i$ ársplanen fram til midten av januar. Har du synspunkter pá innholdet?

Ordet fritt: 